\title{
Preliminary design of system supporting the measurements of noise emission
}

\author{
Wstępny projekt systemu wspomagającego \\ wykonywanie pomiarów emisji hałasu
}

\section{GRZEGORZ SZCZEPAŃSKI LESZEK MORZYŃSKI *}

The article presents the preliminary design of system intended to perform acoustic measurements in an automatic manner. Assumptions of the system were presented, the mechanical and electrical structure of the system were discussed. Result of simulation of motion study was also presented.

KEYWORDS: mobile platform, manipulator, measurement of noise emission

The noise emission tests of machines and devices are carried out using methods that are technically difficult to perform [1]. In this type of research, the repeatability of noise source measurements - often performed in dynamic operating conditions - and (in the case of in situ measurements) background noise prevailing in industrial plants should be ensured. The accuracy of the measurement is influenced by the positioning of the microphone. In general, when measuring the sound power, the direction of the microphone reference (the longitudinal axis of the microphone preamplifier connected to the microphone) should be parallel to the hypothetical measuring surface. In some cases, it is necessary to carry out measurements even at precisely defined points on the measuring surface [2] to correctly determine the quantities associated with emitting noise.

Due to the automation of acoustic measurements, it is possible to increase the accuracy and repeatability of results, as well as significantly shorten the time of measurements [1]. Considering the need for modern technical solutions enabling observation of phenomena and measuring systems ensuring better and better accuracy, as part of the research task carried out at the Central Institute for Labor Protection, the State Research Institute will develop a system supporting measurements related to designation and evaluation of noise emissions from machinery and equipment. It will consist of a mobile platform, manipulator, sound level meter and a set of sensors.

\footnotetext{
* Mgr inż. Grzegorz Szczepański (grszc@ciop.pl), dr inż. Leszek Morzyński (Imorzyns@ciop.pl) - Centralny Instytut Ochrony Pracy - Państwowy Instytut Badawczy
}

\section{Project assumptions}

The system supporting acoustic measurements will be primarily intended for testing the noise emission of machines and devices, including the determination of: the sound power level corrected by the frequency characteristics $A$ and the emission sound pressure level corrected by the frequency characteristic $A$, at the workplace or in other specified places [4]. The basic legal regulations concerning the noise emission of machinery and equipment are contained in the European Directive 2006/42/EC [5] introduced into national legislation by the ordinance of the Minister of Economy of October 21, 2008 on essential machine requirements [6]. The directive obliges designers and constructors to provide the level of sound pressure emitted, corrected by the frequency response $A$, at the workplace - if the value of this pressure exceeds $70 \mathrm{~dB}$. If, however, the level of sound pressure emitted, corrected by the frequency response $A$, in the workplace exceeds 80 $\mathrm{dB}$, the machine manual must contain information on the level of its sound power.

A technical solution adapted to perform emission measurements in an automatic manner can therefore find a wide range of recipients. This solution will be adapted to measuring systems and meters with small dimensions, allowing for remote start of measurement and having battery power supply. The system will also work in measurements in the external environment (in favorable weather conditions, i.e. in the absence of atmospheric precipitation and in the air temperature ensuring the correct operation of all components of the assistive system - in accordance with manufacturers' declarations). However, it should be remembered that meteorological conditions (e.g. temperature and air humidity, atmospheric precipitation) have an effect on sound propagation and - as in the case of classical measurement methods - constitute a limitation.

The mobile platform will be adapted to move on dry and paved surfaces and to cover small elevations, but it will not cope with abrupt ground level differences (with steps) or with boggy terrain. The manipulated element will be a microphone with a preamplifier with a mass not exceeding $0.1 \mathrm{~kg}$. The maximum range of the manipulator will decide on the usefulness of the system, which is why one of the 
assumptions of the project was to develop such a solution that will allow placing the microphone at a height of not less than $2 \mathrm{~m}$ from the ground.

\section{System construction}

The base of the developed solution will be a mobile platform, on which the manipulator will be installed, ensuring proper setting of the microphone at specific points of the space located on the measuring plane. The control system of the system (after entering data concerning the measuring surface) automatically calculates the coordinates of the points.

SolidWorks software version 2018 was used to design the structure and carry out traffic analysis. The system will consist of five groups of elements:

- mechanical construction elements (including mobile platform chassis plates, housing elements, fastening elements for measuring systems and manipulator arms);

- electric drives;

- power sources (two 12 V 9 Ah Li-lon batteries);

- electronic components (including voltage converters and stabilizers, high precision distance sensor, 2D laser scanners type LiDAR, gyroscopes, accelerometers);

- control controllers (including motor controllers for the mobile platform and manipulator actuators as well as the control minicomputer).

The basic element of the mobile platform (fig. 1) is the aluminum chassis plate (made of PA38 alloy), $4 \mathrm{~mm}$ thick and $900 \mathrm{~mm} \times 700 \mathrm{~mm}$, with aluminum profile supports. The mobile platform motors will be mounted on it.

Two safety buttons will be located on the top plate of the mobile platform:

- button for safe stopping of the machine - interrupting all procedures set in an automatic or manual manner;

- emergency stop button - disconnecting the power circuit at one pole.

The system supporting the measurement of noise emissions will be equipped with three information lamps, indicating the operating status:

- green - informing that the system is powered and the systems are working properly, the system is waiting for instructions/executes actions entered manually;

- blue - informing that the system performs the measurement task automatically;

- red - informing that the auxiliary system detected a failure/lack of possible movement in accordance with the measurement procedure.

In order to eliminate the steering rod, it was assumed that each wheel will be equipped with an electric motor, controlled independently by means of a dedicated controller. This will allow the vehicle to rotate around its own axis without the need to complicate the control system.

It was decided to test two types of wheels: conventional wheels with a rubber treadmill and mechanic wheels allowing the vehicle to move in any direction without the need to rotate the mobile platform. The use of this type of solution will make the platform a non-holonomic system with greater maneuverability - also in rooms with very narrow corridors or places with numerous obstacles (i.e. objects protruding above the level of a flat surface).

The BLDC (brushless DC motor) brushless motors are the best to drive the mobile platform, which, compared to brushed motors, are more efficient and lightweight, allow control over a wide range of speeds, and above all are definitely quieter and have a longer lifespan. The choice of brushless DC motors (BLDC) with a supply voltage of $24 \mathrm{~V}$, nominal torque of $0.5 \mathrm{Nm}$ with adjustable speed in the range of $200 \div 3000 \mathrm{rpm}$ and with encoder $1000 \mathrm{imp} / \mathrm{rev}$. For the engines, a worm gear was chosen with a worm wheel made of composite and a shaft driven by $\varnothing 12 \mathrm{~mm}, 60: 1$ ratio and $60 \%$ efficiency.

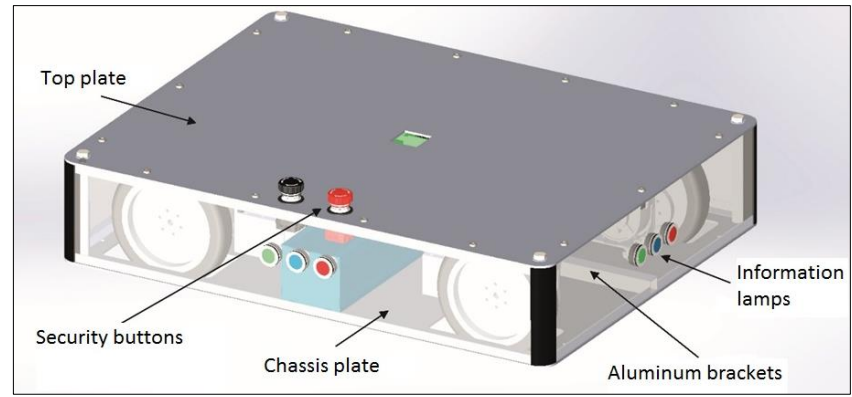

Fig. 1. Mobile platform

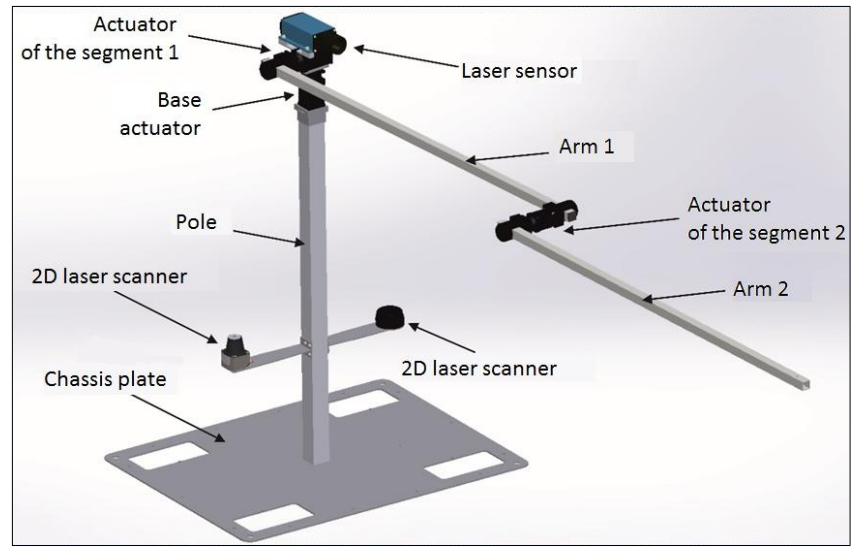

Fig. 2. Manipulator and measuring sensors

In addition, the manipulator design will consist of several fastening elements, actuators and manipulator arms. Fasteners connecting the robot arms with the actuators were designed to be made in FFF (fused filament fabrication) technology on a 3D printer.

The prints will be made of ABS material with increased mechanical properties. For the construction of a micrometer, actuators were selected that are integrated with the gear reduction system, encoder and controller. Their construction is based on a cycloidal gear, which is characterized by high resistance to vibrations and impacts.

The control can be carried out using a controller based on one of the selected transmission standards: RS485, CAN, TTL or Ethercat.

Due to the fact that the manipulated element (microphone) is very light, it was decided to make both manipulators from $25 \mathrm{~mm} \times 25 \mathrm{~mm}$ aluminum sections with a thickness of $2 \mathrm{~mm}$, the length of the elements would be 1.3 to $0.7 \mathrm{~m}$

The manipulator is to be placed on a mast, the height of which has been pre-determined to be $1 \mathrm{~m}$. Distance sensors, including laser scanners from LiDAR, have also been installed on the mast. To install the measuring systems will be used the fasteners located on the surface of the top mobile platform. The elements installed on the chassis plate will be encased with $3 \mathrm{~mm}$ thick acrylic glass plates. The manipulator structure and location of the measuring sensors are shown in fig. 2 .

Due to different supply voltages of individual components, the booster system will be equipped with converters and voltage stabilizers, converting $12 \mathrm{~V}$ DC voltage into $5 \mathrm{~V}$ and $24 \mathrm{~V}$ DC voltages.

The set of sensors includes:

- distance measurement sensors related to the location of the support system relative to the tested object, including 2D laser scanners of LiDAR type and high precision laser distance sensor;

- sensors of the manipulator orientation, including, first of all, accelerometers, gyroscopes and inclinometers.

The basic wiring diagram of electrical components together with the description of the communication bus is shown in fig. 3. 


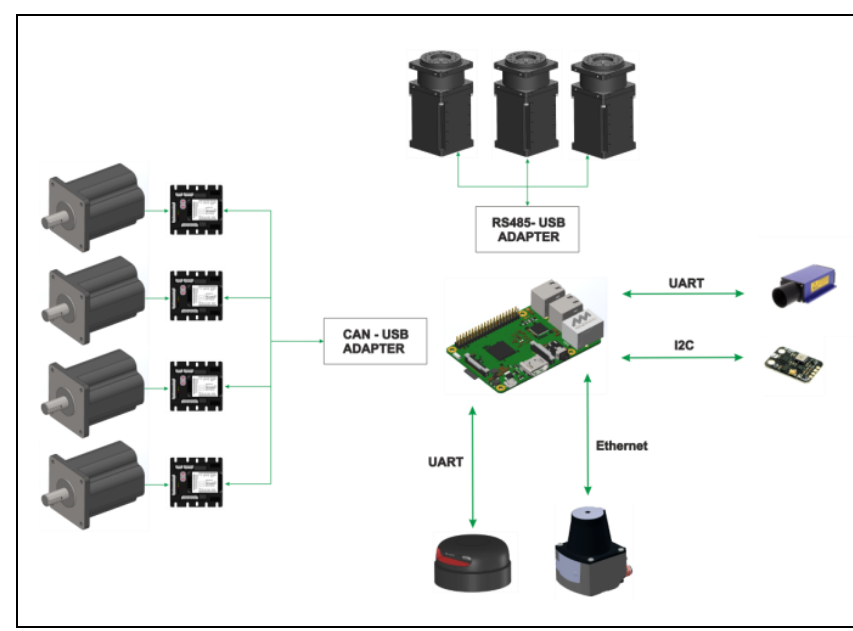

Fig. 3. Simplified diagram of communication connections of system components

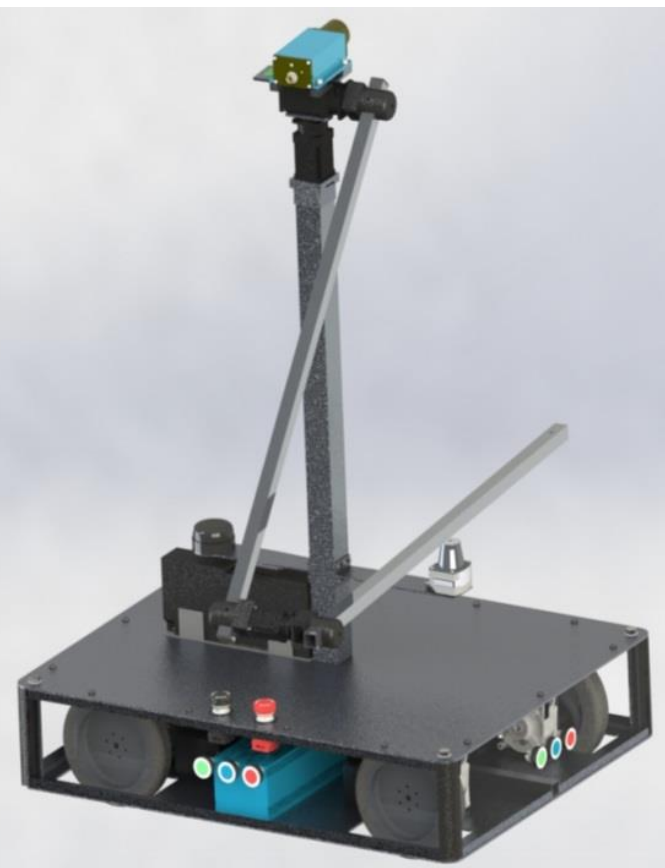

Fig. 4. Visualization of the model of the system supporting the measurement of noise emissions

The control system of the manipulator and mobile platform must meet a number of requirements. Above all, it should provide simultaneous control of all running engines and receive signals from all measuring sensors.

For this purpose, it is planned to use a quad-core Raspberry Pi 3 mini-computer model $B$. The architecture of automated systems software can have different diagrams [7].
Controlling a mobile system with a large number of sensors is a very complex issue, and at the same time a key issue from the point of view of the proper support system positioning - both in laboratory conditions and in difficult industrial conditions. The appropriate software structure will enable quick adaptation of the supporting system to new purposes and possibly to other hardware platforms.

It was decided that the ROS operating system would be used to control the supporting system.

According to estimates, the weight of the system with mechanic wheels should be approx. $44 \mathrm{~kg}$. His model is shown in fig. 4

\section{Simulation tests}

The purpose of the simulation tests was to determine the time course of the torque of the front and rear wheels. Numerical simulations were performed in the SolidWorks 2018 software (in the motion module), using simplified geometric models, which, however, contained key parameters of the final model of the support system.

In simplified models, modified properties related to the mass of the model and the position of the center of mass as well as characteristic dimensions, in accordance with the detailed model were applied. The center of mass of the assistive system model is at a point close to the center of the center of symmetry. The study used classic wheels with a diameter of 8 inches. Simulation studies of mobile platform motion were made for a complex surface (fig. 5), i.e. a flat surface and a $10^{\circ}$ slope. The following wheel contact coefficients with the ground were used [8]:

- kinetic friction coefficient (slip coefficient) $\mu_{\mathrm{k}}=0.76$;

- static friction coefficient $\mu_{\mathrm{s}}=1.0$.

During the simulation, three characteristic phases of motion were analyzed (fig. 5):

- movement of the mobile platform on a flat ground,

- approaching a hill with a slope of $10^{\circ}$,

- driving on a hill, with the chassis parallel to the hill.

The simulation results are shown in fig. 6 and fig. 7 .

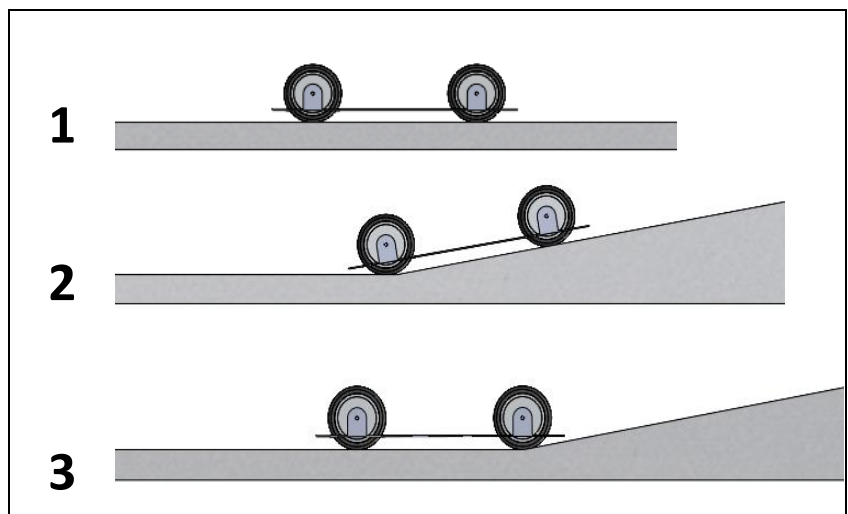

Fig. 5. Characteristic features of the numerical examination

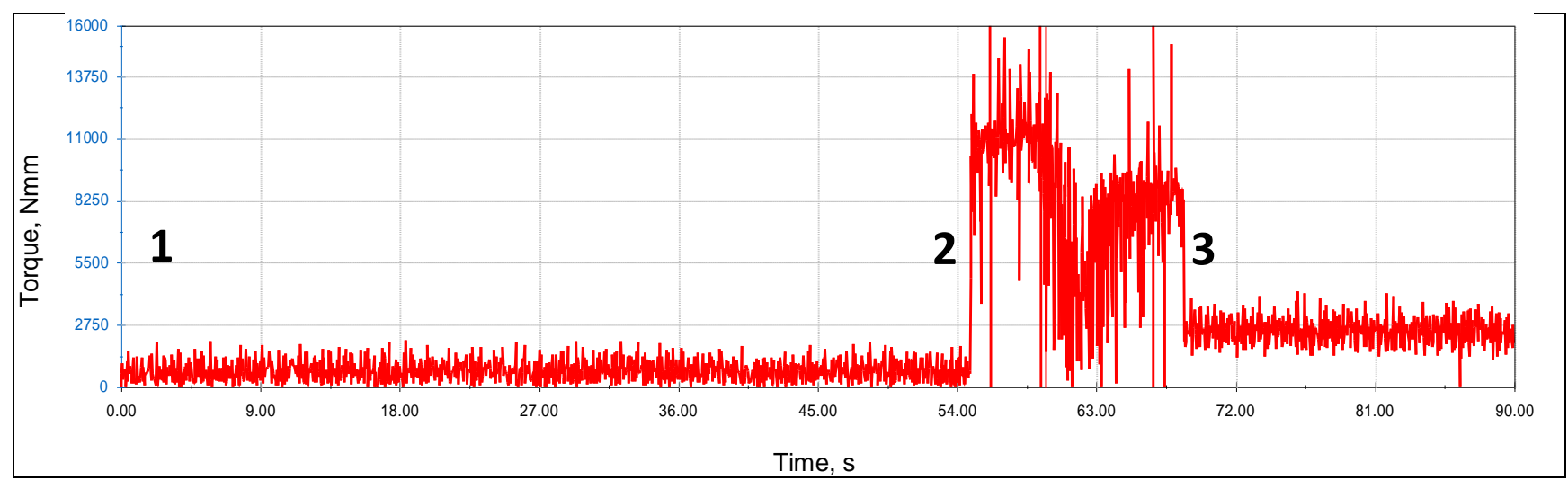

Fig. 6. Graph of the rear wheel torque 


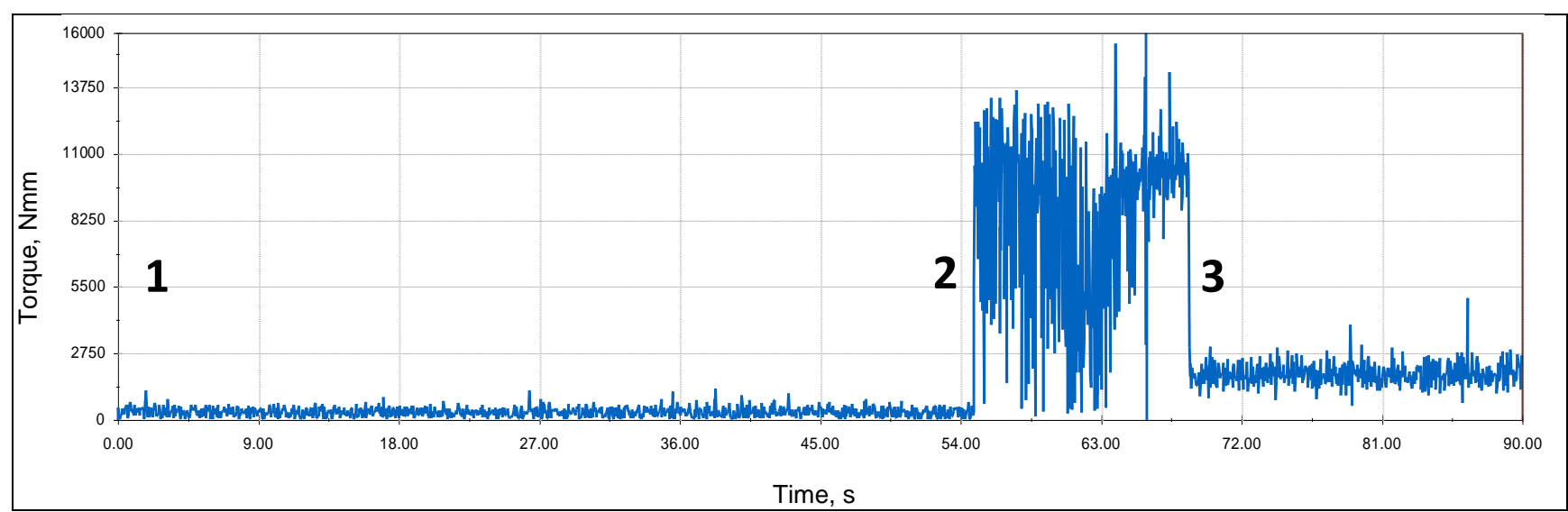

Fig. 7. Torque diagram of the front wheel

The momentary torque occurring during the uphill climb was approx. $12 \mathrm{Nm}$ for the rear wheel and approx. $11 \mathrm{Nm}$ for the front wheel. The continuous torque when driving on a flat surface amounted to an average of $0.5 \mathrm{Nm}$, and at the moment of approaching a hill - approx. 2.7 Nm for the rear wheel and approx. $1.9 \mathrm{Nm}$ for the rear wheel.

Results obtained by numerical research were similar to the analytical results obtained in accordance with the course of the procedure applicable to mobile inspection platforms, presented in the article [9]. These results were used to select drives for the mobile platform.

\section{Conclusions}

The presented system supporting the measurement of noise emission will be used not only in research related to the noise emission of machinery and equipment, but also in the implementation of a series of basic, diagnostic and verification orientations. The developed solution will be used in the measurement of parameters characterizing the noise of large objects in situ, as well as will allow to automate measurements related to the determination of sound power and sound radiation, including in experiments carried out in the chamber for acoustic tests included in Technician laboratories - Safe-Bio Central Institute for Labor Protection - National Research Institute. As part of further work, the construction of a laboratory model and verification tests of the developed solution in laboratory and real conditions were planned.

Prepared on the basis of research carried out in 2017-2018 as part of the statutory activity of the Central Institute for Labor Protection - National Research Institute, financed by the Ministry of Science and Higher Education.

\section{REFERENCES}

1. Engel Z., Piechowicz J., Pleban D., Stryczniewicz L. „Hale przemysłowe, maszyny $i$ urządzenia - wybrane problemy wibroakustyczne". Warszawa: Centralny Instytut Ochrony Pracy - Państwowy Instytut Badawczy, 2009.

2. PN-EN ISO 3744:2011 Akustyka - Wyznaczanie poziomów mocy akustycznej i poziomów energii akustycznej źródeł hałasu na podstawie pomiarów ciśnienia akustycznego Metody techniczne stosowane $\mathrm{w}$ warunkach zbliżonych do pola swobodnego nad płaszczyzną odbijającą dźwięk.

3. Felis J., Flach A., Kamisiński T. "Testing of a device for positioning measuring microphones in anechoic and reverberation chambers". Archives of Acoustics. 37, 2 (2012): pp. $245-250$.
4. PN-EN ISO 11202:2012 Akustyka - Hałas emitowany przez maszyny i urządzenia - Wyznaczanie poziomów ciśnienia akustycznego emisji na stanowisku pracy i w innych określonych miejscach $\mathrm{z}$ zastosowaniem przybliżonych poprawek środowiskowych.

5. Directive 2006/42/EC of the European Parliament and of the Council of 17 May 2006 on machinery, and amending Directive 95/16/EC (recast) (Text with EEA relevance) OJ L 157, 9.6.2006.

6. Rozporządzenie Ministra Gospodarki z 21 października 2008 r. w sprawie zasadniczych wymagań dla maszyn (Dz.U. z 2008 r. nr 199, poz. 1228 ze zm.).

7. Fraser G., Steinbauer G., Weber J., Wotawa F. "Robust Intelligent Control of Mobile Robots, Mobile Computing: Concepts, Methodologies, Tools, and Applications". IGI Global, 2008,

pp. 597-617.

8. Wong J.Y. "Theory of Ground Vehicles". 3rd edition. WileyInterscience, 2001.

9. Kasprzyczak L., Dzikowski A., Nowak D. „Wyznaczanie parametrów elektromechanicznych głównych napędów Mobilnej Platformy Inspekcyjnej". Mechanika i Automatyzacja Górnictwa. 7 (2013): pp. 30-36.

Translation of scientific articles, their computer composition and publishing them on the website www.mechanik.media.pl by original articles in Polish is a task financed from the funds of the Ministry of Science and Higher Education designated for dissemination of science.

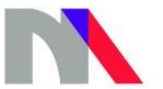

Ministry of Science and Higher Education

Republic of Poland 